*Mestre em Direito pela Fundação Universidade de Itauna (FUIT). Especialista em Direito Público pelo Instituto de Educação Continuada (IEC). Bacharel em Direito pela Fundação Educacional Monsenhor Messias (FEMM). Email: alexmatososilva@gmail. com

** Doutora em Direito pela Pontifícia Universidade Católica de Minas Gerais (PUCMG). Mestre em Direito pela Pontifícia Universidade Católica de Minas Gerais (PUCMG). Bacharel em Direito pela Universidade Federal de Minas Gerais (UFMG). Email: cintiagarabini.com

\section{O Duplo Grau Obrigatório Das Decisões De IMPROCEDÊNCIA EM AÇÕES DE IMPROBIDADE}

\author{
The Compulsory Double Degree Of Jusrisdiction In \\ IMPROBITY ACTIONS
}

\section{Alex Matoso Silva* Cintia Garabini Lages**}

Como citar: SILVA, Alex Matoso. LAGES, Cíntia Garabini. O duplo grau obrigatório das decisões de improcedência em ações de improbidade. Scientia Iuris, Londrina, v. 24, n. 1, p. 165185, mar. 2020. DOI 10.5433/21788189.2020v24n1p165. ISSN $2178-8189$.

Resumo: O presente artigo tem como propósito discutir, à luz do devido processo constitucional e da teoria do modelo constitucional do processo, a validade da submissão de sentenças de improcedência proferidas em ações de improbidade administrativa ao duplo grau de jurisdição obrigatório, especialmente levando-se em conta que, à falta de norma expressa determinante do reexame necessário em tais casos, a submissão tem sido feita à força de aplicação por analogia do disposto no art. 19 da Lei 4.717/65 (Lei da Ação Popular) ou da aplicação subsidiária do art. 496 do CPC. A presente pesquisa, do tipo exploratória, adotará como procedimentos a revisão bibliográfica e a análise documental (julgados), sendo o método de inferência o indutivo. Busca-se validar a hipótese negativa para o reexame necessário, seja porque inaplicável a analogia, seja porque o próprio reexame necessário carece de amparo constitucional.

Palavras-chave: improbidade; reexame necessário; devido processo legal.

\begin{abstract}
The purpose of this paper is to discuss - in the light of due constitutional process and the theory of the constitutional model of the procedure - the validity of the submission of rulings of inadmissibility in actions of administrative improbity to the double degree of compulsory jurisdiction, especially taking into account that, in the absence of an express rule determining the necessary review in such cases, the submission is made by force
\end{abstract}


of application by analogy of the provisions of article 19 of Law 4.717/65 (Law of Class Actions) or by the subsidiary application of article 496 of the Code of Civil Procedure. This exploratory research will adopt as procedures the bibliographical review and the documentary analysis (of ruled cases), being the method of inference the inductive one. It seeks to validate the negative hypothesis for the necessary review, either because the analogy is inapplicable, or because the review itself lacks constitutional protection.

Keywords: improbity; review required; due process. 


\section{INTRODUÇÃO}

O presente trabalho pretende discutir acerca a submissão das sentenças de improcedência nas ações de improbidade administrativa ao duplo grau de jurisdição obrigatório - instituto conhecido como reexame necessário - com fundamento na aplicação analógica do art. 19 da Lei 4.717/65 (Lei da Ação Popular) ou na aplicação subsidiária do artigo 496 do Código de Processo Civil, à luz do modelo constitucional processual brasileiro.

A análise ora apresentada assume como fio condutor as teorias processuais constitucionalistas que têm por objeto a análise das relações decorrentes da constituição e sua aplicação ao processo, tal como formuladas por Eduardo Couture, Baracho e Dias, bem como sua versão mais recente, a teoria do modelo constitucional do processo, desenvolvida por Ítalo Andolina e Giuseppe Vignera. (DIAS, 2012; ANDOLINA, VIGNERA, 1997).

Há que se registrar que estudo foi motivado pela constatação de que os tribunais estaduais, ao submeterem as decisões de improcedência ao reexame necessário (expressão que doravante será utilizada), o fazem - no mais das vezes de ofício - sob a restrita e mera referência à analogia e ao artigo 19 da Lei 4.717/65, que regulamenta o processo e julgamento da ação popular, assim como ao singelo argumento de que se trata de um entendimento consolidado na jurisprudência do Superior Tribunal de Justiça. Um exemplo disso - frise-se: da mera referência ao entendimento "consolidado na jurisprudência do STJ" - foi a decisão do Tribunal de Justiça do Estado de Minas Gerais, datada de 13.11.2018, em sede da Apelação Cível no 1.0396.13.0035613/001, por sua Sexta Câmara Cível, sob a relatoria do desembargador Corrêa Junior. (BRASIL, 2018), assim ementado:

Conheço de ofício da remessa necessária, à luz do artigo 19, da Lei n. 4.717/65, aplicável analogicamente ao caso analisado, nos termos da jurisprudência consolidada pelo c. Superior Tribunal de Justiça:

PROCESSUAL CIVIL. AÇÃO CIVIL PÚBLICA. IMPROBIDADE ADMINISTRATIVA. REEXAME NECESSÁRIO. CABIMENTO. APLICAÇÃO, POR ANALOGIA, DO ART. 19 DA LEI 4.717/1965. 1. "Por aplicação analógica da primeira parte do art. 19 da Lei $n^{\circ} 4.717 / 65$, as sentenças de improcedência de ação civil pública sujeitam-se indistintamente ao reexame necessário" (REsp 1.108.542/SC, Rel. Ministro Castro Meira, j. 19.5.2009, Dje 29.5.2009). 2. Agravo Regimental não provido. (AgRg no REsp 1219033/RJ, Rel. Ministro HERMAN BENJAMIN, SEGUNDA TURMA, julgado em 17/03/2011, DJe 25/04/2011).

Não se pretende analisar criticamente o julgamento no mérito - o reconhecimento ou não da existência de ato ímprobo por parte do réu. Tampouco será objeto de estudo a forma como o Tribunal mineiro invocou a aplicação do reexame necessário ao caso, a mera e restrita referência à analogia e ao artigo 19 da Lei 4.717/65, que regulamenta o processo e julgamento da ação popular.

Assim, por óbvio, a decisão referida serve apenas de exemplo da prática constatada 
(aqui noticiada) e de ponto de partida para se examinar a higidez da aplicação da analogia para a submissão de uma sentença de improcedência em ação de improbidade administrativa ao duplo grau de jurisdição obrigatório, quando, cediço, a referida ação de improbidade conta com rito processual próprio que não prevê a referida submissão.

Quanto à metodologia adotada, a presente pesquisa caracteriza-se como sendo do tipo exploratória e adota como procedimentos a revisão bibliográfica e a análise documental (julgados), sendo o método de inferência o indutivo.

Utiliza-se, como estratégia ao estudo, suscitação escalonada do que aqui se denomina de "dúvidas razoáveis", em número de quatro, cujas respostas ao longo do desenvolvimento do trabalho servirão ao propósito de confirmação ou não da hipótese de conclusão. São elas: a primeira, quanto ao dever de respeito ao contraditório; a segunda, quanto à existência de um silêncio (eloquente) no microssistema da improbidade administrativa quanto à remessa necessária; a terceira, que consubstancia o cerne deste estudo, quanto à obrigatoriedade da submissão da sentença de improcedência ao reexame necessário; e, por fim, a quarta, quanto à existência de identidade do substrato fático a justificar o emprego da analogia.

A hipótese proposta à confirmação futura por efeito deste estudo é a do não cabimento do reexame necessário no procedimento especial da ação de improbidade administrativa, seja porque inaplicável a analogia (inexistência de fundamento juridicamente válido para tanto), seja porque o próprio reexame necessário é exceção aos princípios que integram o modelo constitucional processual brasileiro.

Uma vez que estabelecido o marco teórico na jurisdição concretizada pelo devido processo constitucional, passa-se, a partir do próximo item, a uma breve análise do desenvolvimento processual sob a jurisdição regida nos limites constitucionais.

\section{UMA VISÃO DA JURISDIÇÃO À LUZ DO PRINCÍPIO DO DEVIDO PROCESSO CONSTITUCIONAL}

As relações entre constituição e processo são há muito evidenciadas tanto por processualistas, quanto por constitucionalistas e passam por distintas formas de concepção.

Eduardo Couture, processualista uruguaio, afirmava ser possível deduzir das relações estabelecidas entre a constituição e o processo, uma "Teoria Geral da Tutela Constitucional do Processo", assumindo o processo o papel de garantidor dos direitos da pessoa humana. Nesse contexto teórico, qualquer lei processual que privasse o indivíduo de razoável oportunidade para fazer valer seu direito em juízo, deveria ser considerada inconstitucional. (COUTURE, 1993, p. 150)

José Alfredo de Oliveira Baracho, analisando as contribuições de Couture à Teoria do Processo, afirmou que o reconhecimento do processo como garantidor de direitos humanos 
antecipa a compreensão constitucional do processo. Segundo o constitucionalista mineiro:

Como primeira fonte normativa do Direito Processual, a Constituição determina a organização dos poderes supremos, consagra os princípios fundamentais de suas instituições, possibilitando-lhes um funcionamento harmonioso. O paralelo entre o processo e o regime constitucional em que o mesmo desenvolve é inevitável. É nesse sentido que a relação entre os institutos processuais e seus pressupostos políticos e constitucionais foi ressaltada por Couture: «a ação, como figura particular do direito cívico de petição; a exceção, como direito cívico paralelo à ação; o princípio da igualdade das partes, a garantia constitucional do juiz competente, etc.». (BARACHO, 1982, p. 61).

Entretanto, é possível afirmar que as relações entre constituição e processo se aprofundaram desde a publicação das obras de Couture e Baracho. Segundo Humberto Theodoro Júnior, tais relações evoluíram de forma a poder-se afirmar que, na atualidade, compete ao processo não apenas a garantia de direitos processuais, a garantia de todos os direitos fundamentais. (THEODORO JÚNIOR, 2009, p. 30). Daí utilizar-se no presente trabalho a expressão devido processo constitucional em detrimento daquela referida no próprio texto da Constituição Federal de 1988, que em seu art. $5^{\circ}$, inciso LIV, como devido processo legal.

Isso não se faz por obra do acaso, mas propositalmente. Conforme Ronaldo Brêtas de Carvalho Dias (2004), os poderes do Estado devem ser compreendidos como um complexo sistema de órgãos criados e delimitados pela Constituição. Suas atribuições, bem como a forma de execução das suas competências também encontram definição em normas constitucionais, o que confere legitimidade ao exercício da função jurisdicional. Nesse sentido, afirma referido autor:

Portanto, no Estado Democrático de Direito, que visualizamos como princípio, a função jurisdicional somente se concretiza dentro da moderna e inafastável estrutura constitucionalizada do processo e a declaração final do Estado, decorrente do poder de cumprir o dever de prestá-la, quando e se provocada por qualquer um do povo ou mesmo por qualquer órgão estatal, inserida na decisão, sentença ou provimento ali prolatados, jamais será um ato isolado ou onipotente do órgão jurisdicional, ditando ou criando direitos a seu talante, máxime se fundados na fórmula ilógica, inconstitucional e antidemocrática do "livre (ou prudente) arbítrio do juiz, mas resultado lógico de uma atividade jurídica realizada com a obrigatória participação em contraditório daqueles interessados que suportarão os seus efeitos. (DIAS, 2004, p. 85).

Em sentido convergente ao apresentado por Couture, Baracho e Dias, Italo Andolina e Giuseppe Vignera apresentam uma compreensão complementar das relações estabelecidas entre a constituição e o processo, a partir das quais é possível distinguir uma jurisdicionalidade originária e uma jurisdicionalidade derivada da constituição. A primeira relaciona-se com a "concreta forma de organização e funcionamento do Poder Judiciário", ao passo que a jurisdicionalidade derivada 
seria aquela decorrente de um modelo normativo estruturado constitucionalmente. (LAGES, CHAMON JÚNIR, 2017, p. 296).

A jurisdicionalidade, que pode ser melhor compreendida como o qualitativo da função de jurisdizer, quando assumida como derivada da Constituição, isto é, como instituída constitucionalmente, perfazeria o que os autores denominam com muita precisão de "modelo constitucional do processo": conjunto de normas constitucionais referentes ao exercício da função jurisdicional e que se apresenta como um verdadeiro esquema geral de processo, capaz de se fazer entender como "objeto de uma exposição unitária". (LAGES; CHAMON JÚNIOR, 2017, p. 296).

A jurisdicionalidade derivada, aqui assumida como modelo constitucional processual, caracteriza-se como sendo expansível, variável e aperfeiçoável, o que significa dizer que as normas processuais constitucionais condicionam os diversos procedimentos estabelecidos pelo legislador ordinário, podem ser criados distintos procedimentos, diversas estruturas como forma de atingir resultados desejados e pode o referido modelo ser aperfeiçoado pelo legislador infraconstitucional pela introdução de novos princípios e garantias processuais, possibilitando a sua permanente atualização. (LAGES, CHAMON JÚNIOR, 2017, p. 296).

Dada a centralidade da Constituição na conformação do processo, tal como defendido por Couture, Baracho, Dias, Andolina e Vignera, adota-se no presente trabalho a expressão devido processo constitucional, entendido não como um locus onde se desenvolvem simples formalidades, mas um espaço de garantia dos direitos fundamentais dos participantes do processo e destinatários dos efeitos decorrentes do provimento, ato final que põe fim à cadeia procedimental.

Dentre os princípios que conformam o modelo constitucional processual brasileiro, interessam ao presente trabalho, os princípios do contraditório, da ampla defesa, da isonomia e do dispositivo.

Compreende-se por contraditório a liberdade assegurada àqueles que sofrerão os efeitos do provimento, de participar do processo. Como afirma Gonçalves, com fundamento na teoria processual formulada por Elio Fazzalari, a essência do contraditório reside "na simétrica paridade da participação, nos atos que preparam o provimento, daqueles que nele são interessados porque, como seus destinatários, sofrerão os seus efeitos." (GONÇALVES, 1992, p. 115). O princípio do contraditório, caracterizador do processo, apresenta-se, no contexto teórico fazzalariano, como uma liberdade assegurada de participação, não como dever de participação, como imposição. Imposição se faz ao Estado como sendo aquele que deve assegurar o direito de participação dos contraditores. A estes se resguarda a liberdade de participarem ou não. Ainda segundo Gonçalves,

O contraditório é a garantia da participação das partes, em simétrica igualdade, no processo, e é garantia das partes porque o jogo da contradição é delas, os interesses divergentes são delas, são elas os "interessados e contra-interessados" 
na expressão de FAZZALARI, enquanto, dentre todos os sujeitos do processo, são os únicos destinatários do provimento final, são os únicos sujeitos do processo que terão os efeitos do provimento atingindo a universalidade de seus direitos, ou seja, interferindo imperativamente em seu patrimônio. (GONÇALVES, 1992, p. 127).

O princípio da ampla defesa se corporifica na garantia às partes à livre argumentação, consistente na liberdade assegurada aos contraditores de utilizar de todos os meios legalmente admitidos de se manifestar, mediante representação profissional técnica, em prazo e modo adequados e suficientes e de serem ouvidos em sua manifestação, podendo lançar mão de provas e recursos.

O princípio da isonomia inibe a ocorrência de tratamento processual diverso a uma parte em relação a outra na medida da sua igualdade, de modo o que se facultar ou os ônus e deveres que se imputar a uma será, na mesma medida, aplicada a outra.

Por fim, o princípio do dispositivo, segundo o qual a jurisdição depende, para a sua atuação, da vontade provocadora das partes mediante o exercício do direito de ação. Deste princípio decorre o princípio da voluntariedade no âmbito da Teoria Geral do Sistema Recursal, segundo o qual o conhecimento e processamento de recurso por instância recursal superior exige manifestação inequívoca da parte legitimada interessada. O reexame necessário que assegura, de modo impositivo e não volitivo, o duplo grau de jurisdição, apresenta-se como exceção legal ao princípio da voluntariedade, não obstante não ser considerado recurso em sentido próprio, mas condição de eficácia da decisão.

O modelo constitucional de processo vincula-se à forma moderna, democrática, do estado, a assegurar a legitimidade da atuação estatal no exercício das suas funções. Nesse sentido, Ronaldo Brêtas de Carvalho Dias reafirma:

[...] a importância do processo constitucional na obtenção do pronunciamento estatal decisório reivindicado pelas partes, única forma de lhes permitir, democraticamente, dentro de um espaço procedimental cognitivo-argumentativo informado pelo contraditório e pela ampla defesa, a possibilidade de individualizarem as normas jurídicas abstratas e gerais integrantes do ordenamento jurídico que deverão incidir na solução das particularidades do caso concreto reconstruído dialeticamente no processo. (2012, p. 34).

No mesmo sentido, a advertência de Rosemiro Pereira Leal:

A asserção de que há de se dar tratamento igual a iguais e desigual a desiguais é tautológica, porque, na estruturação do procedimento, o dizer e contradizer, em regime de liberdade assegurada em lei, não se operam pela distinção jurisdicional do economicamente igual ou desigual. O direito ao Processo não tem conteúdos 
de criação de direitos diferenciados pela disparidade econômica das partes, mas é direito assegurador de igualdade de realização construtiva do Procedimento. (2004, p.103).

Essa advertência, em verdade, não veda a admissão de institutos processuais que privilegiem uma das partes, como se mostra ser o reexame necessário, mas evidencia que tais instrumentos somente podem ser estabelecidos no processo de modo a tornar isonômica a oportunidade das partes de interferir na realização construtiva do procedimento, não uma simples condição de paridade - nivelamento formal.

Sendo este o modelo adotado, surge a primeira dúvida razoável: saber se o reexame necessário realmente respeitaria os princípios do contraditório e da ampla defesa (argumentação), quando imposto como condição de eficácia da decisão em proteção a apenas de uma das partes: a pessoa jurídica lesada.

\section{AS AÇÕES DE IMPROBIDADE E SEU MICROSSISTEMAPROCESSUALESPECÍFICO}

A Constituição Federal de 1988, ao estabelecer em seu artigo 37, § $4^{\text {o }}$ que os atos de improbidade administrativa importam na suspensão dos direitos políticos, a perda da função pública, a indisponibilidade dos bens e o ressarcimento ao erário sem prejuízo da ação penal cabível, dotou a ação de improbidade administrativa de caráter manifestamente repressivo.

A ação de improbidade administrativa, disciplinada no art. 17 da Lei 8.429/92, carrega o caráter repressivo constitucionalmente definido, uma vez que a mesma "se destina, precipuamente, a aplicar sanções de natureza pessoal, semelhantes às penais, aos responsáveis por atos de improbidade administrativa, conforme prevê o art. 12 da referida Lei”. (SOARES, 2015).

$\mathrm{Na}$ ação de improbidade, é comum a cumulação do pedido de ressarcimento de danos, o que consubstancia, na ação de improbidade, efeito secundário da punição. Eis aí a razão de se confundir o propósito da ação de improbidade, com o das ações de ressarcimento puras. No entanto, conforme estudo a respeito do tema elaborado por Thiago Oliveira Soares, restam assinalados os propósitos de cada qual, evidenciada a diferença:

Essa distinção foi enfatizada no julgamento do REsp 827.445, perante a $1^{\text {a }}$ Turma (DJ de 08.03.10), quando, em voto-vista, o então ministro do STJ, Teori Zavaski, registrou que, diferentemente do que ocorre com simples demandas anulatórias de ato jurídico ou de reparação de danos, "a ação de improbidade administrativa tem natureza especialíssima, qualificada pela singularidade do seu objeto, que é o de aplicar penalidades a administradores ímprobos e a outras pessoas - físicas ou jurídicas - que com eles se acumpliciam para atuar contra a Administração ou que se beneficiam com o ato de improbidade".

Portanto, trata-se de uma ação de caráter repressivo, semelhante à ação penal, diferente das outras ações com matriz constitucional, como a Ação Popular (CF, art. $5^{\circ}$, LXXIII, disciplinada na Lei 4.717/65), cujo objeto típico é de natureza 
essencialmente desconstitutiva (anulação de atos administrativos ilegítimos) e a Ação Civil Pública para a tutela do patrimônio público (CF, art. 129, III e Lei 7.347/85), cujo objeto típico é de natureza preventiva, desconstitutiva ou reparatória. Na ação de improbidade o objeto principal é aplicar sanções punitivas de caráter pessoal, a saber: a suspensão dos direitos políticos, a perda da função pública, a perda dos bens ou valores acrescidos ilicitamente ao patrimônio, a multa civil e a proibição de contratar com o Poder Público ou receber benefícios ou incentivos fiscais ou creditícios. (SOARES, 2015).

Por conta desses aspectos peculiares, para a ação de improbidade foi constituído um procedimento contraditório específico, inspirado na ritualística processual penal regente dos crimes de responsabilidade dos funcionários públicos, conforme previsto nos art. 513 a 518 do Código de Processo Penal. Ressalte-se apenas que a estruturação de novo procedimento judicial específico é consentânea com a característica da variabilidade que informa o do modelo constitucional processual, segundo a qual o modelo constitucional do processo pode vir a assumir diversas formas para a obtenção de fins específicos, no caso concreto, a responsabilização individual do responsável pela prática de ato ímprobo. (LAGES, CHAMON JÚNIOR, 2017, p. 296; ANDOLINA, VIGNERA, 1997, p. 09).

A inspiração está revelada na referência ao inquérito policial (art. 22) para apuração de qualquer ilícito previsto na Lei 8.429/92 (Lei da Improbidade Administrativa ou, abreviadamente, LIA) e no estabelecimento de uma fase de notificação e de defesa preliminar como pressupostos ao recebimento da inicial (conforme art. 17, $\S \S 8^{\circ}$ e $9^{\circ}$, da Lei 8.429/92), que guarda paralelo à forma prevista no art. 514 do Código de Processo Penal.

Afora isso, é bastante peculiar, no procedimento da ação de improbidade administrativa, quando proposta pelo Ministério Público, a faculdade atribuída à pessoa jurídica de direito público lesada de se posicionar no processo em função do interesse defendido, aderindo à pretensão ministerial ou sustentando a defesa do ato impugnado. Neste sentido, estabelece expressamente a Lei da Improbidade Administrativa, em seu art. 17, $\S 3^{\circ}$, a incidência do disposto no $\S 3^{\circ}$ do art. $6^{\circ}$ da Lei da Ação Popular, segundo a qual: "A pessoa jurídica de direito público ou de direito privado, cujo ato seja objeto de impugnação, poderá abster-se de contestar o pedido, ou poderá atuar ao lado do autor, desde que isso se afigure útil ao interesse público, a juízo do respectivo representante legal ou dirigente". Mais que isso, é permitido até mesmo, no curso da demanda, alterar-se de um polo a outro a posição da pessoa jurídica de direito público lesada. Veja-se, a tal respeito, o entendimento adotado por Luiz Manoel Gomes Junior e Rogério Favreto, em obra coletiva coordenada por Gajardoni:

A regra do $\S 3^{\circ}$ do art. 17 da Lei de Improbidade Administrativa determina a aplicação da norma do art. $6^{\circ}, \S 3^{\circ}$, da Lei da Ação Popular que permite, segundo juízo de conveniência do representante legal da pessoa de direito público interessada, escolher a posição que será adotada quando a ação de improbidade administrativa tiver sido ajuizada pelo Ministério Público. 
Assim, temos as seguintes possibilidades para a pessoa jurídica de direito público interessada: a) contestar o pedido, se entender que o Ministério Público não tem razão; b) ingressar no polo ativo, se entender que o Ministério Público tem razão e; c) aderir parcialmente ao pedido, em caso de reconhecimento pontual; d) permanecer inerte, sem qualquer manifestação, não havendo qualquer consequência no plano processual ou no de direito material. (GAJARDONI, 2012, p. 272-273).

Esse entendimento foi albergado pela Segunda Turma do Superior Tribunal de Justiça, no julgamento do REsp 945.238/SP (BRASIL, 2008):

PROCESSUAL CIVIL. AÇÃO POPULAR. MIGRAÇÃO DE ENTE PÚBLICO PARA O POLO ATIVO APÓS A CONTESTAÇÃO. PRECLUSÃO. NÃOOCORRÊNCIA.

1. Hipótese em que o Tribunal a quo concluiu que o ente público somente pode migrar para o polo ativo da demanda logo após a citação, sob pena de preclusão, nos termos do art. 183 do Código de Processo Civil.

2. O deslocamento de pessoa jurídica de Direito Público do polo passivo para o ativo na Ação Popular é possível, desde que útil ao interesse público, a juízo do representante legal ou do dirigente, nos moldes do art. $6^{\circ}, \S 3^{\circ}$, da Lei 4.717/1965. 3. Não há falar em preclusão do direito, pois, além de a mencionada lei não trazer limitação quanto ao momento em que deve ser realizada a migração, o seu art. 17 preceitua que a entidade pode, ainda que tenha contestado a ação, proceder à execução da sentença na parte que lhe caiba, ficando evidente a viabilidade de composição do polo ativo a qualquer tempo. Precedentes do STJ.

4. Recurso Especial provido.

A Lei da Improbidade Administrativa estabeleceu procedimento contraditório judicial especial, ao mesmo tempo em que restringiu a aplicação subsidiária de normas processuais constantes de diplomas legais outros, com exceção das situações expressamente por ela previstas. Nesse sentido o disposto no artigo $14, \S 3^{\circ}$, no art. $16, \S 1^{\circ}$, art. $17, \S \S 3^{\circ}$ e $6^{\circ}$ da Lei de Improbidade.

Em relação ao reexame necessário, tem-se que o mesmo configura exceção ao princípio do dispositivo, do contraditório e da ampla defesa, ao possibilitar a devolução ao órgão judicial $a d$ quem dos fundamentos da decisão proferida na instância a quo, sem a correspondente garantia da participação dos demais contraditores, possíveis afetados por uma decisão reformadora da mesma. Sua aplicação, dado o seu caráter excepcional, depende de expressa previsão legal. No entanto, a Lei de Improbidade Administrativa não faz referência expressa à possibilidade de sua aplicação, como não prevê a possibilidade da sua adoção a partir da aplicação de dispositivos legais outros. A questão que poderia ser levantada neste caso, a permitir a submissão da decisão a reexame necessário seria a de uma interpretação extensiva baseada no chamado silêncio eloquente. Ademais, a Lei da Improbidade Administrativa, ao estruturar um procedimento contraditório especial para punir atos de improbidade, não obstante prever a possibilidade da presença da pessoa jurídica de direito público lesada como contraditora, não tem o propósito de proteger - de modo primário - 
dita pessoa jurídica de direito público, senão a coletividade.

Surge, a partir da consideração de possível ocorrência de silêncio eloquente, a segunda dúvida razoável: se o reexame necessário aqui sob crítica estaria acolhido no microssistema processual das ações de improbidade.

Isso porque proposta a ação pelo Ministério Público - um dos legitimados extraordinários previstos pela referida lei - a participação da pessoa jurídica de direito público lesada na qualidade de legitimada extraordinária e, portanto, contraditória, é facultativa, sendo que, na eventualidade da sua participação, ela pode assumir posição processual diversa daquela do autor em face do provimento, nos termos do disposto no $\S 3^{\circ}$ do art. $17^{\circ}$, com sua referência expressa à incidência do estabelecido no $\S 3^{\circ}$ do art. $6^{\circ}$ da Lei $4.717 / 65$, e do entendimento consubstanciado no julgamento do REsp 945.238/SP pelo Superior Tribunal de Justiça (contestar o pedido, abster-se de contestar, atuar ao lado do autor - no caso, o Ministério Público - e mudar de polo da demanda no curso do processo).

Considerando as várias possibilidades de participação da pessoa jurídica de direito público no processo, uma terceira dúvida razoável aparece: saber se a simples existência de provimento contendo decisão denegatória do pedido formulado ensejaria o reexame necessário do mesmo nos termos do art. 496, I, do Código de Processo Civil.

Esta terceira dúvida ora lançada é de vital importância, porque uma resposta negativa a ela desnaturaria o pressuposto e impediria per si a obrigatoriedade de submissão da sentença de improcedência prolatada em ações de improbidade ao duplo grau de jurisdição.

\section{O DUPLO GRAU DE JURISDIÇÃO E O REEXAME NECESSÁRIO}

Ernane Fidelis asseverava que "O inconformismo com a decisão única é manifestação comum do ser humano, por mais justa que se possa apresentar". (SANTOS, 2006, p. 637). Dito inconformismo constitui a base do princípio do duplo grau de jurisdição, que significa em uma conceituação simplista a previsibilidade de que - na jurisdição ordinária - uma decisão judicial seja revista por um órgão hierarquicamente superior, se assim a parte sucumbente ou um terceiro interessado o desejar.

O desejo referido linhas atrás - traduzido como interesse qualificado juridicamente concretiza-se na manifestação recursal, que conduz a decisão impugnada ao crivo da instância superior, mediante um novo julgamento, com análise dos pontos delimitados no inconformismo - tantum devolutum quantum apellatum - brocardo latino que traduzido no efeito devolutivo do recurso.

Revolvidos e reanalisados os fatos, uma nova decisão será proferida na causa, podendo seu conteúdo confirmar os argumentos contidos na primeira decisão (a decisão impugnada), estabelecer uma conclusão diversa (reforma) ou ainda impor a anulação daquela (à força de 
reconhecimento de vício nela presente), cumprindo-se o mister de inconformismo da parte com a justeza do que ficou decidido.

Historicamente, o duplo grau de jurisdição era previsto expressamente na Constituição de 1824 , em seu art. $158 .{ }^{1}$ Desde então, as constituições que se seguiram limitaram-se a prever a existência de tribunais e sua competência recursal, donde se extrai a existência implícita do princípio do duplo grau de jurisdição. Ao lado disso, por utilização literal da expressão recursos no art. $5^{\circ}$, inciso $\mathrm{LVI}^{2}$, da Constituição Federal de 1988, resta evidente, como garantia constitucional o duplo grau de jurisdição.

Até então, nesse tópico foi tratada a oportunidade de revisão de uma decisão judicial por um órgão hierarquicamente superior, cuja previsão de garantia em nível constitucional atribui faculdade à parte sucumbente utilizar dessa garantia.

Em nível infraconstitucional, conforme art. 496, inciso I ${ }^{3}$, do Código de Processo Civil, como pressuposto de produção de efeitos, está prevista a submissão ao duplo grau de jurisdição, obrigatoriamente, as sentenças proferidas contra a União, os Estados, o Distrito Federal, os Municípios e suas respectivas autarquias e fundações de direito público.

Não há dúvida de que, pela literalidade do caput do art. 496 do Código de Processo Civil e conforme lição de Donizete, o reexame necessário:

[...] não deve ser considerado recurso, seja por lhe faltar tipicidade, seja por não deter diversos dos requisitos básicos exigidos para caracterização dos recursos, tais como a necessidade de fundamentação, o interesse em recorrer, a tempestividade, o preparo, entre outros. Por esse motivo, entende-se que a remessa necessária tem natureza jurídica de condição de eficácia da sentença, não se relacionando, portanto, com os recursos previstos na legislação processual. (2017).

Evidente trata-se de um instituto criado e mantido (até hoje) com o fim de privilegiar a Fazenda Pública e que é utilizado por ela tão somente para postergar o cumprimento de decisões que lhes sejam contrárias, porquanto, incidente sobre a condição de eficácia da sentença, ainda que não haja recurso voluntário por parte dela, não é permitida a execução definitiva dos julgados, a qual, mais das vezes, carece de expedição de precatório para pagamento.

Entretanto, perceptível uma tendência à restrição do instituto do reexame necessário no âmbito do Direito Processual brasileiro, o que pode ser verificado pela determinação legal da sua não aplicação em função do valor da condenação, nos termos dos incisos I, II e III do § terceiro do

1 Art. 158. Para julgar as Causas em segunda, e última instância haverá nas Provincias do Imperio as Relações, que forem necessarias para commodidade dos Povos.

2 Art. $5^{\circ} \mathrm{LV}$ - aos litigantes, em processo judicial ou administrativo, e aos acusados em geral são assegurados o contraditório e ampla defesa, com os meios e recursos a ela inerentes;

3 Art. 496. Está sujeita ao duplo grau de jurisdição, não produzindo efeito senão depois de confirmada pelo tribunal, a sentença: I - proferida contra a União, os Estados, o Distrito Federal, os Municípios e suas respectivas autarquias e fundações de direito público; 
art. 496 do Código de Processo Civil, bem como da limitação por consolidação de entendimento por tribunais, nos termos dos incisos dos $\S 4^{\circ}$ do referido art. 496 do CPC.

A esse respeito, Nelson Nery Jr e Rosamaria de Andrade Nery fazem consignar que:

O controvertido instituto, não poucas vezes (e não sem razão, pela aplicação que se lhe tem dado), acoimado de inconstitucional, sofreu, na vigência do CPC/1973, mitigação legislativa (v.g., L 10352/01, LJEFed 13), deixando de incidir em numerosos casos, razão bastante para orientar o intérprete a restringir sua aplicação, quando isso mostrar-se razoável. [...]. O novo CPC também operou mais algumas restrições à remessa necessária que visam limitar o abuso do instituto por parte da Fazenda Pública e dar maior garantia de satisfação àquele que vence demanda instaurada contra ela. (2015, p. 1173).

Cabe lembrar, também em conformidade com o registro anotado pelo professor Donizete, que

[...] os arts. 13 da Lei $\mathrm{n}^{\circ} 10.259 / 2001$ e 11 da Lei $\mathrm{n}^{\circ}$ 12.153/2009, que tratam, respectivamente, dos Juizados Especiais Cíveis e Criminais no âmbito da Justiça Federal e Juizados Especiais da Fazenda Pública no âmbito dos Estados, do Distrito Federal, dos Territórios e dos Municípios, proibiram, expressamente, o reexame necessário nas causas dos respectivos juizados. (DONIZETE, 2017).

De todo modo, porque ainda existente, esse privilégio à Fazenda Pública é abusivo se considerado o caráter integral do reexame, o que significa dizer que por meio dele são devolvidas ao tribunal todas as questões jurídicas e fáticas discutidas na instância anterior, ainda que a sentença não as tenha examinado em sua totalidade, permissivo de que o órgão jurisdicional hierarquicamente superior julgue a causa novamente por inteiro, sem qualquer restrição. Nesse sentido é a lição de Guilherme Marinoni:

1. Remessa necessária. Sendo cabível, a submissão à remessa necessária constitui condição inarredável para que se dê o trânsito em julgado da decisão (Súmula 423, STF: "não transita em julgado a sentença por haver omitido o recurso ex officio, que se considera interposto ex lege"). A remessa necessária - também conhecida como reexame necessário - não constitui figura recursal, porque lhe falta a voluntariedade inerente aos recursos. Trata-se de condição para a eficácia da sentença e para a formação da coisa julgada. A remessa necessária “devolve ao Tribunal o reexame de todas as parcelas da condenação suportadas pela Fazenda Pública, inclusive dos honorários de advogado" (Súmula 325, STJ). Como se trata de expediente voltado à defesa dos interesses da Fazenda Pública em juízo, nele "é defeso, ao Tribunal, agravar a condenação imposta à Fazenda Pública" (Súmula 45, STJ). (MARINONI, 2017, p. 600).

Cabe ressaltar ainda que por força do entendimento consubstanciado no enunciado da Súmula 45 do Superior Tribunal de Justiça, inadmissível a reformatio in pejus em de reexame 
necessário.

Eis que, então, surge a quarta dúvida razoável: tendo por conta que o reexame necessário é uma prerrogativa exclusiva da Fazenda Pública, seria o mesmo compatível com o modelo constitucional brasileiro, especialmente considerada a garantia do devido processo constitucional e do contraditório, enquanto garantia de participação em simétrica paridade?

\section{DA ANALOGIA E SUA APLICAÇÃO NO PROCEDIMENTO DE IMPROBIDADE ADMINISTRATIVA}

No tópico de introdução, registrou-se que o motivo desta pesquisa fora, tendo como exemplo o julgamento da apelação cível nº 1.0396.13.003561-3/001, pela Sexta Câmara Cível do Tribunal de Justiça do Estado de Minas Gerais, a específica submissão a reexame necessário de uma sentença de improcedência prolatada em uma ação de improbidade, ao fundamento da aplicação de analogia, de modo que os contornos jurídicos do instituto analogia tornaram-se de especial importância neste estudo, para verificar o seu adequado emprego no caso julgado.

Cediço que, em algumas situações, um caso concreto não encontra norma jurídica capaz de regular a situação de fato nele versada. A isso se denomina lacuna legislativa, que, para o devido tratamento do caso, deve ser colmatada por meio de técnicas de integração.

Segundo Carlos Maximiliano, a analogia tem origem na Matemática e consiste na verificação de semelhança de relações. (2011, p. 168). Não configura método interpretativo, mas procedimento de colmatação de lacuna, prevista de modo expresso no artigo $4^{\circ}$. da Lei de Introdução às Normas do Direito Brasileiro: "quando a lei for omissa, o juiz decidirá o caso de acordo com a analogia, os costumes e os princípios gerais de direito”.

A analogia consubstancia técnica de suprimento de lacunas de normatização para um dado caso concreto e "consiste em aplicar a caso não previsto a norma legal concernente a uma hipótese prevista e, por isso mesmo, tipificada.” (AMARAL, 2003, p. 90).

Duas são as espécies de analogia: a analogia legal e a analogia jurídica. A primeira delas analogia legal - consiste em fazer incidir ao caso em exame uma norma existente no ordenamento jurídico, que regulamenta situação fática diversa, porém semelhante. A segunda - analogia jurídica - implica extrair do ordenamento jurídico com um todo, por meio do auxílio da doutrina, da jurisprudência e dos princípios gerais do direito, uma norma capaz de regular o caso concreto em exame.

Na hipótese em análise no presente artigo, discute-se a possibilidade da aplicação da analogia legal, porque utilizada a hipótese do reexame necessário previsto no artigo 19 da Leia da Ação Popular para fins de incidência ao procedimento estabelecido pela Lei de Improbidade Administrativa.

A analogia legal apresenta pressupostos específicos a saber: “a) o caso deve ser 
absolutamente não previsto em lei; b) deve existir, pelo menos, um elemento de identidade entre o caso previsto e o não previsto; c) a identidade entre os dois casos deve atender a ratio legis." (AMARAL, 2003, p. 91).

A doutrina (FRANÇA, 1988, p. 67) também aponta que a utilização da analogia encontra limites e, assim, especialmente, não pode ser aplicada uma norma criada para uma hipótese excepcional a casos que não apresentem tais características.

Também, conforme entendimento consolidado no âmbito do Direito Penal (FRANÇA, 1988, p. 67), ou mais adequadamente para o propósito deste trabalho no âmbito do Direito Punitivo (ínsito nas ações de improbidade administrativa), não se pode aplicar analogia in mala partem.

Certo está que a submissão de sentenças de improcedências em ações de improbidade administrativa ao reexame necessária não está prevista em lei, de modo que se tem por cumprido o primeiro pressuposto listado pelo professor Francisco Amaral à utilização da analogia.

No entanto, aqui surge a quinta e última dúvida razoável: haveria um elemento de identidade entre o caso previsto (a ação popular) e o não previsto (ação de improbidade) e, em havendo, se dita identidade atende a ratio legis.

\section{DA NÃO APLICAÇÃO DO REEXAME NECESSÁRIO NOS PROCEDIMENTOS DE IMPROBIDADE ADMINISTRATIVA}

Durante o desenvolvimento deste trabalho, foram levantados vários questionamentos, os quais aqui encontram suas respectivas e necessárias respostas.

Indagou-se se o reexame necessário respeitaria os princípios do contraditório (em sua dimensão formal e substancial) e da ampla defesa (manifestação), assim também o devido processo constitucional, posto consubstanciar uma condição de eficácia da decisão em proteção a apenas de uma das partes: o Estado.

Também, se seria possível inferir a aplicação do reexame necessário nos procedimentos de improbidade administrativa a partir do reconhecimento da omissão quanto ao mesmo como um silêncio eloquente, a permitir uma interpretação extensiva.

Se estaria correto afirmar que uma decisão de improcedência em ação de improbidade administrativa seja decisão proferida contra a União, os Estados, o Distrito Federal e suas respectivas autarquias e fundações de direito público cumpre o pressuposto para o reexame necessário, conforme disposto no art. 496, I, do Código de Processo Civil.

Ainda, considerado reexame necessário um privilégio reconhecido exclusivamente à Fazenda Pública, se existiria albergue constitucional para o seu reconhecimento não apenas no âmbito dos procedimentos de improbidade administrativa, mas em todos os procedimentos constituídos sob o modelo processual constitucional brasileiro. 
E, na hipótese dos questionamentos acima autorizassem o reconhecimento do reexame necessário no âmbito do Direito Processual brasileiro, se haveria um nexo de identidade entre o caso previsto (a ação popular) e o não-previsto (ação de improbidade) a autorizar sua aplicação nesta através da aplicação da analogia legal.

No que concerne ao respeito ao modelo constitucional do processo, em especial aos princípios do contraditório (enquanto garantia de participação dos contraditores em simétrica paridade de armas) e da ampla defesa (manifestação, direito à ampla argumentação), que delineou os contornos da primeira indagação, cabe concluir que o reexame necessário, em seus próprios limites (ao largo da interposição de recursos voluntários) transforma o Poder Judiciário censor de si mesmo, sem qualquer fundamento razoável e, a partir de então, alijando das partes o direito de "ser ouvido" e do "poder de influência" na construção da decisão do órgão hierarquicamente superior não sustenta a condição do devido processo constitucional.

É, pois, até desnecessário registrar que o fato de não permitir as partes qualquer manifestação dirigida ao órgão hierarquicamente superior viola o princípio constitucional processual da ampla defesa.

Relativamente à dúvida - se o reexame necessário estaria acobertado no microssistema processual próprio das ações de improbidade - a constatação é negativa.

Com efeito, o silêncio eloquente a respeito da incidência de reexame necessário em ações de improbidade administrativa importaria no reconhecimento de uma norma contrária à aplicação do instituto do reexame necessário, mesmo porque seria inapropriado admitir uma revisão automática da decisão de improcedência em âmbito de ação nitidamente punitiva, com origens no direito penal e processual penal.

Avançando-se à terceira dúvida - da possibilidade da afirmação de que uma decisão de improcedência em ação de improbidade administrativa seja decisão proferida contra a União, os Estados, o Distrito Federal e suas respectivas autarquias e fundações de direito público e, assim, cumpriria o pressuposto para o reexame necessário, conforme disposto no art. 496, I, do Código de Processo Civil - resta óbvio que tal condição não ocorre.

Conforme discutido anteriormente, a ação de improbidade administrativa nunca teve o propósito de proteger - de modo primário - as pessoas jurídicas de direito público (União, Estados, Distrito Federal e suas respectivas autarquias e fundações de direito público), mas a sociedade, a coletividade. $\mathrm{O}$ resguardo a ditas pessoas jurídicas é secundário, consequencial, tanto que a posição delas no procedimento não é previamente estabelecida, dependendo de cada caso concreto.

É possível concluir categoricamente que uma sentença de improcedência em ação de improbidade não é proferida contra a contra a União, os Estados, o Distrito Federal e suas respectivas autarquias e fundações de direito público, mas sim contra o agente público responsável pelo ato de improbidade, nos termos do artigo $1^{\circ}$ da Lei de Improbidade Administrativa. 
Em sendo assim, o pressuposto estabelecido no inciso I do art. 496 do Código de Processo Civil não é suficiente a autorizar a aplicação do reexame necessário.

Restou assinalada na quarta dúvida se existiria albergue constitucional para que o instituto do reexame necessário pudesse sobreviver, especialmente considerada a garantia do contraditório e do devido processo legal, tendo em conta que dito instituto - o reexame necessário - configura uma prerrogativa da Fazenda Pública.

Relembrando o magistério do professor Rosemiro Pereira Leal, o direito ao processo é um direito assegurador de igualdade de realização construtiva do procedimento. Nesse passo, ainda que se possa admitir tratamento diferenciado a uma das partes no processo, para o fim de estabelecer igualdade, ter-se-á por violado o princípio da isonomia sempre que dito tratamento diferenciado não for razoável. (LEAL, 2004, p. 104).

Impossível extrair qualquer traço de razoabilidade em um instituto que serve a privilegiar as pessoas jurídicas de direito público inventado tão somente para permitir a elas postergar a execução de julgados que lhes sejam contrários, o qual, afora dito propósito, pretende seja aplicado forçosamente às ações de improbidade administrativa como instrumento de censura às decisões de improcedência neste âmbito.

Por fim, quanto à possibilidade do reconhecimento da aplicação do reexame necessário através da aplicação da analogia, foi questionada a existência de elemento de identidade entre a norma positivada (a ação popular) e a situação de lacuna (ação de improbidade), que permitiria a incidência da norma positivada no procedimento da ação popular por analogia, e, em havendo identidade, se ela atenderia a ratio legis.

Conquanto admissível que seja comum à ação popular e à ação de improbidade a tutela ressarcitória do patrimônio público, impossível desconhecer, em relação a esta última, que isso traduz uma consequência secundária, jamais por coincidência de objetos.

Com efeito, embora seja objeto da ação popular a tutela ao patrimônio público, moralidade administrativa, meio ambiente e patrimônio histórico e cultural, de conformidade com o disposto no art. 5, inciso LXXIII, da Constituição Federal de 1988, não está no propósito primário da ação de improbidade a proteção patrimonial de pessoas jurídicas de direito público. Então, em havendo dano provocado pela conduta ímproba, o ressarcimento ao erário, que, conforme enfaticamente assinalado, não é a finalidade primeira desta espécie de ação, será imposto ao agente por força da disposição contida no art. $5^{\circ}$ da Lei 8.429/924.

E dizer, enquanto a ação de improbidade tem por função essencial a aplicação das sanções por ato improbidade administrativa e apenas por consequência assessória a reparação do dano ao patrimônio público, sendo este derivado da conduta ilícita administrativa, a ação popular tem por finalidade primária a tutela ao patrimônio público, moralidade administrativa, meio

4 Art. $5^{\circ}$ Ocorrendo lesão ao patrimônio público por ação ou omissão, dolosa ou culposa, do agente ou de terceiro, dar-se-á o integral ressarcimento do dano. 
ambiente e patrimônio histórico e cultural (CF, art. 5, LXXIII). Aliás, Rodolfo Mancuso aponta finalidade da ação popular a "desconstituição do ato lesivo e condenação dos responsáveis à reposição dos status quo ante, permitida a tutela cautelar", não assinalando propósito de aplicação de penalidades pessoais. (MANCUSO, 2004, p. 37).

São ações com expressiva distinção de objetos e finalidades, com convergência apenas acidentalmente no propósito de tutela patrimonialista, não havendo o necessário elemento de identidade entre o caso previsto (a ação popular) e o caso não previsto (ação de improbidade).

E, se por descuido, o intérprete admitir como elemento de identidade entre ambas o elemento da tutela ressarcitória, não será ele, exatamente por sua natureza não primária, o fundamento de atendimento a ratio legis, pois, necessário a tanto eleger um elemento secundário ao posto de primordial para alcançar o intento de atendimento à razão da lei cuja aplicação é pretendida à forma de analogia.

\section{CONCLUSÃO}

O problema proposto no presente trabalho foi o perquirir acerca da possibilidade da submissão das sentenças de improcedência nas ações de improbidade administrativa, ao duplo grau de jurisdição obrigatório, com fundamento na aplicação analógica do art. 19 da Lei 4.717/65 (Lei da Ação Popular), ou na aplicação subsidiária do artigo 496 do Código de Processo Civil.

A partir da reconstrução papel central que a Constituição desempenha no delineamento de um modelo processual de observância obrigatória, sobretudo dos princípios do devido processo constitucional e do contraditório, procedeu-se à análise do procedimento específico da improbidade administrativa, aqui considerado como um microssistema processual.

Restou demonstrado o caráter sancionatório, que o diferencia das demais ações coletivas protetoras do patrimônio público e outros direitos difusos.

Ressaltou-se de modo incisivo as distintas posições subjetivas que a pessoa jurídica de direito público interno pode assumir em face do provimento, a depender da singularidade do caso concreto, posições estas que decorrem dos distintos interesses que a administração pública pode vir a defender no âmbito processual.

Foi discutido também o reexame necessário em face do princípio do duplo grau de jurisdição, buscando evidenciar o seu caráter total, ao devolver toda a matéria discutida ao longo do iter procedimental, ao mesmo tempo em negado aos demais interessados o direito de defesa dos argumentos contidos na decisão recorrida.

Por fim, foi alvo de discussão saber se o reexame necessário poderia ser adotado nos procedimentos de improbidade através da analogia legal, considerando-se uma possível semelhança entre os procedimentos de improbidade e da ação popular. O estudo contido no presente ensaio permite afirmar que ambos os procedimentos diferenciam-se quanto à sua natureza, objeto e fins. 
Conclui-se que o reexame necessário não apenas padece de fundamento constitucional, o que por si só impediria a sua aplicação a qualquer procedimento judicial, bem como não pode ser aplicado ao procedimento de improbidade administrativa em função do caráter sancionatório da lei em face do agente público responsável pela prática do ato ímprobo.

A analogia, enquanto recurso de integração do ordenamento jurídico, não se aplica ao presente caso, pois se o silêncio do legislador pode ser interpretado eloquentemente é no sentido de interpretar uma exceção, o reexame necessário, de forma restritiva.

A conclusão geral é a confirmação da hipótese proposta quanto à impossibilidade do reexame necessário em ações de improbidade administrativa, seja porque inaplicável a analogia (inexistência de fundamento juridicamente válido para tanto), seja porque o próprio reexame necessário, de modo geral, não encontra amparo constitucional na Carta de 1988.

\section{REFERÊNCIAS}

AMARAL, Francisco. Direito civil: introdução. 5. ed., Rio de Janeiro: Renovar, 2003.

ANDOLINA, Italo; VIGNERA, Giuseppe. I fondamenti costituzionali della giustizia civile: il modello costituzionale del processo civile italiano. Torino: G. Giappichelli Editore, 1997.

BARACHO, José Alfredo de Oliveira. Processo e Constituição: o Devido Processo Legal. Revista da Faculdade de Direito da Universidade Federal de Minas Gerais. Belo Horizonte, no. 23-25. p. 59-103, 1982. Disponível em: https://www.direito.ufmg.br/revista/index.php/ revista/article/view/907/850/ Acesso em 02 abr. 2019.

BRASIL. Superior Tribunal de Justiça. REsp n⿳0 945.238/SP, da Segunda Turma, Relator: Ministro Herman Benjamin. Brasília, DF, 9 de dezembro de 2008, DJe 20.04.2009.

BRASIL. Superior Tribunal de Justiça. AgRg no REsp no 1.219.033/RJ, da Segunda Turma, Relator: Ministro Herman Benjamin. Brasília, DF, 17 de março de 2011, DJe 25.04.2011.

BRASIL. Tribunal de Justiça do Estado de Minas Gerais. Apelação Cível no 1.0396.13.0035613/001, da Sexta Câmara Cível, Relator: Desembargador Corrêa Junior. Belo Horizonte, MG, 13 de novembro de 2008, DJe 23.11.2018.

COUTURE, Eduardo J. Fundamentos del derecho procesal civil. 3. ed., Buenos Aires: Depalma, 1993.

DIAS, Ronaldo Brêtas de Carvalho. Responsabilidade do estado pela função jurisdicional. Belo Horizonte: Del Rey, 2004.

Rey, 2012.

. Processo constitucional e estado democrático de direito. 2. ed. Belo Horizonte: Del 
DIDIER JR, Fredie. Curso de direito processual civil, parte geral e processo de conheciment $o$. 17. ed., Salvador: Jus Podivm, 2015.

DONIZETTI, Elpídio. Remessa necessária (art. 496, CPC/2015). Disponível em <http:// genjuridico.com.br/2017/08/23/remessa-necessária-art-496-cpc2015/>. Acesso em: 26 nov. 2018.

FRANÇA, Rubens Limongi. Hermenêutica jurídica. 2. ed., São Paulo: Saraiva, 1988.

GAJARDONI, Fernando da Fonseca, et al. Comentários à lei de improbidade administrativa. 2. ed., São Paulo: Revista dos Tribunais, 2012.

GONÇALVES, Aroldo Plínio. Técnica Processual e Teoria do Processo. Rio de Janeiro: Aide Editora, 1992.

LAGES, Cintia Garabini; CHAMON JÚNIOR, Lúcio Antônio. Acerca da segurança jurídica e da uniformidade das decisões a partir do novo código de processo civil à luz do modelo constitucional do processo brasileiro. Revista Brasileira de Políticas Públicas. Brasília, volume 07, no. 02, p. 286-302, agosto 2017. Disponível em: https://www.publicacoesacademicas. uniceub.br/RBPP/article/view/4797. Acesso em: 08 abr. 2019.

LEAL, Rosemiro Pereira. Teoria geral do processo. 5. ed., São Paulo: Thomson-IOB, 2004.

MANCUSO, Rodolfo de Camargo. Ação popular. 4. ed., São Paulo: Revista dos Tribunais, 2001.

MAXIMILIANO, Carlos. Hermenêutica e aplicação do Direito. Rio de janeiro: Forense editora, 2011.

MARINONI, Luiz Guilherme; ARENHART, Sérgio Cruz; MITIDIERO, Daniel. Novo código de processo civil comentado. 3. ed., São Paulo: Revista dos Tribunais, 2017.

NERY JUNIOR, Nelson; NERY, Rosa Maria de Andrade. Comentários ao código de processo civil. Novo CPC - Lei 13.105/2015, São Paulo: Revista dos Tribunais, 2015.

SANTOS, Ernane Fidelis. Manual de direito processual civil: volume 1: processo de conhecimento. 11. ed., São Paulo: Saraiva, 2006.

SOARES, Thiago Oliveira. O especialíssimo procedimento da Lei n. ${ }^{\circ}$ 8.429/92 somente é aplicável às ações típicas de improbidade administrativa. Publicado em 2015, por Alexandre Bitencourth Hayne. Disponível em: <https://hayne.jusbrasil.com.br/artigos/312150737/oespecialissimo-procedimento-da-lei-n-8429-92-somente-e-aplicavel-as-acoes-tipicas-deimprobidade-administrativa>. Acesso em: 26 nov. 2018.

THEODORO JÚNIOR, Humberto. Direito Processual Constitucional. Revista Estação Científica. Juiz de Fora, v. 01, no. 04, p. 28-43, outubro e novembro de 2009. Disponível em: http://portal.estacio.br/media/4410/artigo-2-revisado.pdf. Acesso em 08 abr. 2019. 
Como citar: SILVA, Alex Matoso. LAGES, Cíntia Garabini. O duplo grau obrigatório das decisões de improcedência em ações de improbidade. Scientia Iuris, Londrina, v. 24, n. 1, p. 165-185, mar. 2020. DOI 10.5433/21788189.2020v24n1p165. ISSN 2178-8189.

Recebido em: 18/03/2019

Aceito em: 24/11/2019 